\title{
Prevelance of Brucellosis among Febrile Negative Malaria Patients by PCR in Northern Kordofan State, Sudan
}

Reham Abdelhady ${ }^{1^{*}}$, Aymen Abdelhaleem ${ }^{2}$, Khalid Anan ${ }^{3}$, Abdelrahim Mohamed Elhussein $^{3}$, Mohammed O Hussien ${ }^{3}$, ELamain E Mohammed ${ }^{1}$ and Isam M Elkhidir $^{4}$

${ }^{1}$ Department of Medical Microbiology, Faculty of Medical Laboratory Science, El Neelain University, Khartoum, Sudan

${ }^{2}$ Medical Research Center, Jazan University, Jazan, Saudi Arabia

${ }^{3}$ Department of Virology, Central Laboratory, The Ministry of Higher Education and Scientific Research, Khartoum, Sudan

${ }^{4}$ Department of Microbiology and Parasitology, Faculty of Medicine University of Khartoum, Khartoum, Sudan

*Corresponding author: Reham Abdelhady, Department of Medical Microbiology, Faculty of Medical Laboratory Science, El Neelain University, Khartoum, Sudan; Email: rehamabdelhady89@gmail.com

Received date: April 11, 2017; Accepted date: August 09, 2017; Published date: August 12, 2017

Copyright:@2017 Abdelhady R, et al. This is an open-access article distributed under the terms of the Creative Commons Attribution License, which permits unrestricted use, distribution, and reproduction in any medium, provided the original author and source are credited.

\begin{abstract}
Background: Diagnosis of Brucellosis is still facing some obstacles; to date it depends on conventional diagnosis based on blood culture and serological methods. PCR method now days offers the hope of rapid diagnosis.
\end{abstract}

Aim: To determine the prevalence of brucellosis among malaria negative febrile patients in Northern kordofan State, Sudan.

Methods: In this cross sectional study, one hundred blood samples were collected from febrile malaria negative patients of different ages form North kordofan State during the period from April to May 2016, and examined by Rose Bengal Plate Test (RBPT), ELISA and nested PCR methods.

Results: The results showed 40 samples were positive by RBPT method 52 samples were positive by ELISA and 81 sample positive by nested PCR.

Conclusion: There was high prevalence of brucellosis among the study population as detected by the three tests. Further studies using various diagnostic methods should be considered to determine the prevalence of human brucellosis at the national level.

Keywords: Brucella; PCR; ELISA; RBPT; Negative malaria patients; Sudan

\section{Introduction}

Brucellosis is one of the most common zoonotic diseases worldwide [1]. The disease is caused by Brucella spp. Four of 6 nomen species of the genus Brucella are pathogenic for humans, i.e., $B$. melitensis (transmitted from sheep and goats), B. abortus (from cattle and other bovidae), B. suis (from pigs), and B. canis (from dogs) [2].

Mediterranean basin (Portugal, Spain, Southern France, Italy, Greece, Turkey, North Africa), Mexico, South \& Central America, Eastern Europe, Asia, Africa, the Caribbean and the Middle East are listed by CDC as high risk areas for brucellosis [3]. Even though countries like UK, Australia, New Zealand, Japan and Canada have been declared Brucella free, half a million new cases of human brucellosis are annually reported worldwide $[4,5]$.

The disease primarily presents as fever of unknown origin with multiple clinical signs and symptoms. Patients regularly suffer serious focal complications such as spondylitis, neurobrucellosis or Brucella endocarditis [6]. The clinical features and presentation of human brucellosis overlap with many other infectious and noninfectious diseases [7] such as typhoid fever, rheumatic fever, spinal tuberculosis, pyelitis, cholecystitis, thrombophlebitis, autoimmune disease, and tumours $[8,9]$. The clinical picture is not specific and laboratory testing should support the diagnosis. An accurate diagnosis is important, as therapeutic failure and relapse, a chronic course, and sometimes severe complications such as bone and joint involvement are characteristic of the disease [10].

Presumptive diagnosis of brucellosis can be made by the use of several serological tests to Brucella antibodies, but the "gold standard" remains isolation and identification of the bacterium. However, cultural examinations are time-consuming, hazardous and not sensitive and can only detect the organism in 10\%-70\% of suspected infections (Moyer and holocomb, 1995). Despite the vigorous attempt for more than one century to come up with a definitive diagnostic technique for brucellosis, diagnosis still relies on the combination of several tests to avoid false negative results [11]. A large number of different tests have been used for the serological diagnosis of brucellosis thus demonstrating the lack of an ideal technique. The sensitivity of these serological tests ranges from $65 \%$ to $95 \%$, but their specificity in areas of endemicity is low, because of the high prevalence of antibodies in the healthy population. Moreover, most serological tests can produce cross-reactions with other bacteria, and they also have important limitations during the early phases of the disease, in persons whose occupations involve exposure to Brucella species, in patients with a recent history of brucellosis, and in patients who 
undergo relapse $[12,13]$. Cultural methods are as well difficult because the Brucellae are facultative intracellular pathogens and their numbers found in patients are normally low [14], Most studies of PCR assays involving human brucellosis have been undertaken with whole blood samples and in these studies different extraction methods, the use of different primer pairs, different target genes and different amounts of DNA were applied. Whole blood was used as clinical specimen in all the studies, but the authors differed in the amount of human DNA that should be added to each PCR assay $[15,16]$. Recently, Zerva et al. [17] used serum instead of whole-blood samples for the diagnosis of human brucellosis by PCR. Serum offers several advantages for nucleic acid amplification methods since inhibition by anticoagulants, hemoglobin, human DNA, or any other substances present in blood but not in serum is alleviated.

The excellent sensitivity reported by Matar and Morata, using the primers B4/B5, in the diagnosis of human brucellosis has not been reproduced by any other group $[17,18]$.

\section{Material and Methods}

\section{Data collection}

Ethical approval for this study was obtained from EL Neelain University and informed written consent was obtained regarding data and blood samples collection from each patient. Only patients who agreed to participate were enrolled in this study.

\section{Inclusion and exclusion criteria}

The study included malaria negative febrile patient who has contact with animal and/or consume raw milk product. Febrile malaria positive patients were excluded.

\section{Sample collection}

A total of 100 blood samples were collected from febrile malaria negative patients who have contact with animal and/or consume raw milk product from Northern kordofan State during the period from April to May 2016. Collected blood samples were centrifuged at 5000 $\mathrm{rpm}$ for $5 \mathrm{~min}$ to obtain the serum. The serum was immediately stored at $-20^{\circ} \mathrm{C}$ until used.

\section{Serological methods}

Rose bengal plate agglutination: The Rose Bengal plate agglutination test (RBPT) antigen (produced by the Central Veterinary Research Laboratories Khartoum, Sudan) was used. For this test $30 \mu \mathrm{l}$ of plain serum is dispensed on a white glossy ceramic tile and mixed with an equal volume of RBT antigen.

Definite clumping/agglutination were considered as positive reaction, whereas no clumping/agglutination were considered as negative for RBPT.

In house Indirect ELISA for Brucella abortus IgM antibody: This inhouse Elisa test was developed by one of the authors (EEM) at the Department of Medical microbiology, Faculty of Medical Laboratory Science, El Neelain University, Khartoum, Sudan. The anti IgM conjugate was obtained from a commercial (VIRCELL, S.L. Pza., Spain)

A hundred $\mu$ of Brucella abortus antigen diluted in coating buffer was added to each well of the 96-wells ELISA plates and incubated overnight at $4^{\circ} \mathrm{C}$. After washing for three times with a washing buffer, $200 \mu \mathrm{l}$ of blocking buffer was added to each well and incubated for $1 \mathrm{~h}$ at $37^{\circ} \mathrm{C}$. Following washing for three times, $100 \mu \mathrm{l}$ of pre-diluted samples, positive and negative controls $(1: 100)$ were added in to appropriate wells and incubated for $1 \mathrm{~h}$ at $37^{\circ} \mathrm{C}$. After washing for three times $100 \mu \mathrm{l}$ of anti-human IgM conjugate was added to each well and incubated for $1 \mathrm{~h}$ at $37^{\circ} \mathrm{C}$. After three more washes, $100 \mu \mathrm{l}$ of substrate solution Tetramethylbenzidine (TMB) and Hydrogen Peroxide $\left(\mathrm{H}_{2} \mathrm{O}_{2}\right)$ was added to each well. The reaction mixture was then incubated for $20 \mathrm{~min}$ at room temperature in the dark. $100 \mu \mathrm{l}$ of stop solution $\left(2 \mathrm{NH}_{2} \mathrm{SO}_{4}\right)$ was then added to each well. Finally, the optical density was measured using micro-plate reader instrument (Asys Expert Plus, Austria) at $450 \mathrm{~nm}$. The mean absorbance (O.D) for each set of duplicate controls and samples was calculated.

\section{Polymerase chain reaction (PCR)}

DNA Extraction: DNA extraction was done by Saturated sodium chloride method as mentioned by Miller et al. $300 \mu$ l of blood samples were resuspended in $1.5 \mathrm{ml}$ Eppendorf's tube with $1000 \mu \mathrm{l}$ red cell lysis buffer (RCLB), mixed well and centrifuged at $5000 \mathrm{rpm}$ for $10 \mathrm{~min}$, Supernatant was discarded and $300 \mu \mathrm{l}$ of white cell lysis buffer (WCLB) was added, $10 \mu \mathrm{l}$ of $10 \%$ SDS and $20 \mu \mathrm{l}$ of protein's K solution were then added and the mixture was incubated for $1 \mathrm{~h}$ at $65^{\circ} \mathrm{C}$. Then $100 \mu \mathrm{l}$ of $6 \mathrm{M} \mathrm{NaCl}$ was added followed by $200 \mu \mathrm{l}$ of cold chloroform and centrifuged at $18000 \mathrm{rpm}$ for 6 min supernatant containing the DNA was then transferred to a new tube and absolute ethanol was added and centrifuged at $14000 \mathrm{rpm}$ for $5 \mathrm{~min}$. The supernatant was then discharged and the pellet was washed with $600 \mu \mathrm{l} 70 \%$ ethanol and centrifuged at $6000 \mathrm{rpm}$ for $5 \mathrm{~min}$, the ethanol was discarded and the pellets were resuspended in $100 \mu \mathrm{DW}$, and stored at $-20^{\circ} \mathrm{C}$ until used [19].

Nested PCR: Four primers for the nested PCR were synthesized according to Agricultural Industry Criteria of the People's Republic of China (NY/T 1467e2007) [8]. These were Bp1 (50-CGT GCC GCA ATT ACC CTC-30), Bp2 (50-CCG TCA GCT TGG CTT CGA-30), Bp3 (50-GAT GCT GCCCGC CCG ATA A-30) and Bp4 (50-GCA CCG AGC GAG CCT TGA AA-30). Amplifications were carried out over two rounds of PCR in a Mastercycler Personal (Biometra, Germany) in volumes of $50 \mathrm{ml}$ containing 1 PCR buffer, $2 \mathrm{mM} \mathrm{MgCl}$, $200 \mathrm{mM}$ each deoxynucleoside triphosphate, 1 mMeach primer, $200 \mathrm{e} 400 \mathrm{ng}$ of genomic DNA and 2.5 U of DNA polymerase. Using the primers of Bp1 and Bp2, the first PCR amplification consisted of an initial denaturation step at $95 \mathrm{C}$ for $5 \mathrm{~min}$, followed by 35 cycles of denaturation at $94 \mathrm{C}$ for $1 \mathrm{~min}$, annealing at $49 \mathrm{C}$ for $1 \mathrm{~min}$, elongation at $72 \mathrm{C}$ for $1 \mathrm{~min}$, and concluded with a final extension step for $10 \mathrm{~min}$ at $72 \mathrm{C}$. Using the $\mathrm{Bp} 3$ and $\mathrm{Bp} 4$ primers and the first-round PCR product as template, the second amplification proceeded through a total of 20 cycles comprising denaturation at $94 \mathrm{C}$ for $30 \mathrm{~s}$, annealing at $51 \mathrm{C}$ for $1 \mathrm{~min}$, primer extension at $72 \mathrm{C}$ for $1 \mathrm{~min}$ and a final extension of $6 \mathrm{~min}$ at $72 \mathrm{C}$. The second round PCR products were electrophoresed on a $1 \%$ agarose gel, and the target amplicon was 419 bp.

Data analysis: The data were analyzed using the statistical package for the social sciences (SPSS version 20). Cross tabulation-Chi-square and Kappa values were used to compare the different test. 
Page 3 of 4

\section{Results}

Out of the 100 samples tested, 81 sample were positive by PCR; 52 sample positive by ELISA; 40 positive by RBPT (Table 1), and 4 samples were negative in all the tests. ELISA detected 4 samples as positive that were negative in the rest of the tests. There were 4 samples that were positive by ELISA and RBPT but negative in the PCR. Three samples negative by PCR were positive in the serological tests while 49 samples that were negative by serological tests were positive in PCR. There were 26 ELISA and PCR positive samples that were negative in the RBPT and 22 samples were positive in all the test. The agreement between I-ELISA and RBPT (0.48) Table 4, between I-ELISA and PCR (0.37) Table 2, and between RBPT and PCR (0.43) Table 3.

\begin{tabular}{|l|l|l|l|}
\hline Test & Positive & Negative & Total \\
\hline RBPT & $40(40 \%)$ & $60(60 \%)$ & 100 \\
\hline ELISA & $52(52 \%)$ & $48(48 \%)$ & 100 \\
\hline PCR & $81(81 \%)$ & $19(19 \%)$ & 100 \\
\hline
\end{tabular}

Table 1: Detection Frequencies of brucellosis infection in malaria negative febrile patient from north kordofan State using RPBT ,ELISA, and PCR.

\begin{tabular}{|l|l|l|l|}
\hline Test & PCR +ve & PCR -ve & Total \\
\hline ELISA Positive (+ve) & 46 & 7 & 53 \\
\hline ELISA Negative (-ve) & 30 & 9 & 39 \\
\hline Total & 76 & 16 & 62 \\
\hline Kappa value $=0.37$ & &
\end{tabular}

Table 2: Cross tabulation of PCR and ELSA results.

\begin{tabular}{|l|l|l|l|}
\hline Test & PCR +ve & PCR -ve & Total \\
\hline $\begin{array}{l}\text { Rose bengal } \\
\text { Positive (+ve) }\end{array}$ & 32 & 8 & 40 \\
\hline $\begin{array}{l}\text { Rose bengal } \\
\text { Negative (-ve) }\end{array}$ & 50 & 10 & 60 \\
\hline Total & 82 & 18 & 100 \\
\hline Kappa value $=0.43$ & & & \\
\hline
\end{tabular}

Table 3: Cross tabulation of PCR and Rospengal results.

\begin{tabular}{|l|l|l|l|}
\hline Test & ELISA +ve & ELISA -ve & Total \\
\hline $\begin{array}{l}\text { Rose Bengal } \\
\text { Positive }(+\mathrm{ve})\end{array}$ & 23 & 14 & 37 \\
\hline $\begin{array}{l}\text { Rose bengal } \\
\text { Negative }(-\mathrm{ve})\end{array}$ & 29 & 26 & 55 \\
\hline Total & 52 & 40 & 92 \\
\hline Kappa value $=0.48$ & & & \\
\hline
\end{tabular}

Table 4: Cross tabulation of ELISA and Rose Bengal results.

\section{Discussion}

Symptoms and signs of human brucellosis are not specific [13,20-22]. Hence, exact diagnosis of brucellosis cannot just be based on clinical symptoms, because it presents similar symptoms to other diseases such as malaria, typhoid and leptospirosis. Therefore isolation of organism in culture or identification of organism by serological and molecular methods for confirming clinical diagnosis is necessary $[23,24]$.

Our results indicated high incidence of brucellosis in patients with fever in north kordofan state, irrespective of the test used. This is hardly surprising since this State is rich In animal wealth especially camels which are known to have high prevalence of brucella infection [25].

Our results also showed that PCR revealed the highest sensitivity in detecting brucella infection (81\%) indicating that most of our patients were at the acute phases of the disease, it also indicate that PCR is probably the method of choice for diagnosis of brucellosis in the feverish patients in endemic areas [26].

Kapaa analysis of ours results revealed highest agreement (0.48) between RBPT and the in- house IgM ELISA. This is plausible as both tests are capable of detecting IgM antibodies which are the first antibodies to appear in early stages of infection.

Kappa analyses also showed moderate correlation between RBPT and PCR (0.43) and lower correlation between ELISA and PCR (0.37) this could be attributed to the fact that RBPT is known as highly sensitive test that could detect both IgM and IgG antibodies while our ELISA was only designed to detect IgM antibodies.

The results also validate the locally developed in-house ELISA as a good diagnostic test that identified (52\%) of the patients as suffering from brucellosis campared to RBPT (40\%). It would be interesting to compare this ELISA with other serological tests such as standard tube agglutination test (SAT) and complement fixation test (CFT) it also of interest to investigate the ability of these tests to monitor such patients after receiving treatment especially the use of PCR to confirm recovery from infection.

Our result also showed few sample that were positive by ELISA and RBPT tests but negative by PCR. This may indicate that the level of bacteremia in these samples might have been lower than the detection threshold of PCR.

Finally, our findings strongly suggest that patients with brucellosis in N. Kordofan were likely to leave the hospital without the specific treatment for brucellosis. This agrees with recent findings that showed that clinicians in Kenya continue to treat febrile patients for presumptive malaria, resulting in missed opportunities to accurately detect and treat other causes of fever [11,27]. The results also highlight the usefulness of nested PCR as a complementary assay to both ELISA and RBPT as a diagnostic approach in diagnosis of acute brucellosis and the need to establish national and regional reference laboratories with facilities for performing nested PCR assay $[28,29]$.

\section{Conclusion}

Definitive diagnosis of brucellosis remains a difficult task. No single test is perfect, clinical history coupled with combination of two or more tests reduces diagnostic errors. The combination of serological and molecular is a good diagnostic criterion. Independent of the disease stage, PCR techniques are more sensitive and more specific 
Citation: Abdelhady R, Abdelhaleem A, Anan K, Elhussein AM, Hussien MO, et al. (2017) Prevelance of Brucellosis among Febrile Negative Malaria Patients by PCR in Northern Kordofan State, Sudan. Clin Microbiol 6: 293. doi:10.4172/2327-5073.1000293

Page 4 of 4

than serological tests. Establishment of Molecular methods could be a useful tool for detection of Brucella spp.

\section{Acknowledgments}

Staff members of the virology Department, Central laboratory are highly acknowledged for their help and provision.

\section{References}

1. Pappas G, Papadimitriou P, Akritidis N, Christou L, Tsianos EV (2006) The new global map of human brucellosis. Lancet Infect Dis 6: 91-99.

2. Godfroid J, Cloeckaert A, Liautard JP, Köhler S, Fretin D, et al. (2005) From the discovery of the Malta fever's agent to the discovery of a marine mammal reservoir, brucellosis has continuously been a re-emerging zoonosis. Vet Res 36: 313-326.

3. Areas at Risk. Centers for disease control and prevention.

4. Purwar S (2007) Human Brucellosis: A Burden of Half-Million Cases per Year. South Med J 102: 1074

5. Colmenero JD, Reguera JM, Martos F, Sánchez-De-Mora D, Delgado M (1996) Complications associated with Brucella melitensis infection a study of 530 cases. Medicine (Baltimore) 75: 195-211.

6. Araj GF (1999) Human brucellosis: a classical infectious disease with persistent diagnostic challenges. Clin Lab Sci 12: 207-212.

7. Lulu AR, Araj GF, Khateeb MI, Mustafa MY, Yusuf AR (1988) Human brucellosis in Kuwait: a prospective study of 400 cases. Q J Med 66: 39-54.

8. Young EJ, Corbel MJ (1989) Brucellosis: clinical and laboratory aspects. CRC Press Inc, Florida, USA, 1989.

9. Al Dahouk S, Tomaso H, Nöckler K, Neubauer H, Frangoulidis D (2003) Laboratory-based diagnosis of brucellosis--a review of the literature. Part II: serological tests for brucellosis. Clin Lab 49: 577-589.

10. Poiester FP, Nielsen K, Samartino LE, Yu WL (2010) Diagnosis of Brucellosis. Open Vet Sci J 4: 46-60.

11. Young EJ (1995) An overview of human brucellosis. Clin Infect Dis 21: 283-90.

12. Ariza J (2002) Brucellosis in the 21st century. Med Clin (Barc) 119: 339-334.

13. Gamazo C, Vitas AI, GoniI L, Diaz R, Morrion I (1993) Factor affecting detection of Brucella melitensis by BACTEC NR730, a nonradiometric system for hemocultures. J Clin Microbiol 31: 3200-3203.

14. Leal-Klevezas DS, Martinez-Vazquez IO, Martinez-Soriano JP (1995) Single-step PCR for detection of Brucella spp. from blood and milk of infected animals. J Clin Microbiol 33: 3087-3090.
15. Morata P, Queipo-Ortuno MI, Colmenero JD (1998) Strategy for optimizing DNA ampliథcation in a peripheral blood PCR assay used for diagnosis of human brucellosis. J Clin Microbiol 36: 2443-2446.

16. Zerva L, Bourantas K, Mitka S, Kansouzidou A, Legakis NJ (2001) Serum is the preferred clinical specimen for diagnosis of human brucellosis by PCR. J Clin Microbiol 39: 1661-1664.

17. Navarro E, Fernandez JA, Escribano J, Solera J (1999) PCR assay for diagnosis of human brucellosis. J Clin Microbiol 37: 1654.

18. Miller SA, Dykes DD, Polesky HF (1988) A simple salting out procedure forextracting DNA from human nucleated cells. Nucleic Acids Res 16: 1215.

19. Franco MP, Mulder M, Gilman RH, Smits HL (2007) Human brucellosis. Lancet Infect Dis 7: 775-786.

20. Mantur BG, Amaranth SK, Shinde RS (2007) Review of clinical and laboratory features of human brucellosis. Indian J Med Microbiol 25: 188-202.

21. Shen MW (2008) Diagnostic and therapeutic challenges of childhood brucellosis in a nonendemic country. Pediatrics121: e1178-e1183.

22. Richtzenhain LJ, Cortez A, Heinemann MB, Soares RM, Sakamoto SM, et al. (2002) A multiplex PCR for the detection of Brucella spp. and Leptospira spp. DNA from aborted bovine fetuses. Vet Microbiol 87: 139-147.

23. Leal-Klevezas DS, Martinez-Vazquez IO, Lopez-Merino A, MartinezSoriano JP (1995) Single-step PCR for detection of Brucella spp. from blood and milk of infected animals. J Clin Microbiol 33: 3087-3090.

24. Omer MM, Musa MT, Bakhiet MR, Perrett L (2010) Brucellosis in camels , cattle and humans :associations and evaluation of serological tests used for diagnosis of disease in certain nomadic localities in Sudan. Rev Sci Tech 29: 663-669.

25. Moyer NP, Holcomb LA, Murray PR, Baron EJ, et al. (1995) Editors: Manual of clinicalmicrobiology. 6th edition. Washington DC ASM Press 549-555.

26. Guerra H (2007) The Brucellae and their success as pathogens. Crit Rev Microbiol 33: 325-331.

27. Zerva L, Bourantas K, Mitka S, Kansouzidou A, Legakis NJ (2001) Serum is the preferred clinical specimen for the diagnosis of human brucellosis by PCR. J Clin Microbiol 39: 1661-1664.

28. Queipo-Ortuno MI, Morata P, Ocon P, Manchado P, Colmenero JD (1997) Rapid diagnosis of human brucellosis by peripheral blood PCR assay. J Clin Microbiol 35: 2927-2930.

29. Matar GM, Khneisser IA, Abdelnoor AM (1996) Rapid laboratory con \$rmation of human brucellosis by PCR anallysis of a target sequence on the 31-kilodalton Brucella antigen DNA. J Clin Microbiol 34: 477-478. 